\title{
EFFECT OF NENAS HONEY SUPPLEMENTATION ON THE OXIDATIVE STATUS OF UNDERGRADUATE STUDENTS
}

\author{
J.A. Goon *a , C. K. Choor ${ }^{\text {b }}$, R. Nur AinaA ${ }^{\mathrm{a}}$, X.Q. Sze ${ }^{\mathrm{a}}$, M. Syahriah ${ }^{\mathrm{a}}$, M.S. Nurul Syamimi ${ }^{\mathrm{a}}$, \\ S. Muhamad Rashidi ${ }^{\mathrm{a}}$, M.A. MardiYAnna ${ }^{\mathrm{a}}$ and J. ZAKIAH ${ }^{\mathrm{a}}$ \\ ${ }^{a}$ Department of Biochemistry, Faculty of Medicine, Universiti Kebangsaan Malaysia, \\ Jalan Raja Muda Abdul Aziz, 50300 Kuala Lumpur. Malaysia \\ ${ }^{b}$ Department of Medicine, Universiti Kebangsaan Malaysia Medical Center, Jalan Jaacob Latif, \\ Bandar Tun Razak, Cheras, 56000 Kuala Lumpur. Malaysia
}

(Received: 23 October 2012; accepted: 23 November 2012)

\begin{abstract}
Honey is a dietary antioxidant as it contains phenolic compounds, such as flavonoids and phenolic acids. Antioxidants are non-nutritive, biologically active ingredients in food that reduce oxidative stress. The antioxidant content in each type of honey varies depending on its source. This study was aimed to determine the effect of Nenas honey supplementation on the oxidative status of a group of healthy medical students. They were divided into two groups; control $(n=10)$ and supplemented $(n=13)$, where 1 tablespoon of Nenas honey was given each day. Blood sampling was done at baseline, $1^{\text {st }}$ and $2^{\text {nd }}$ month of the study for determination of DNA damage and antioxidant enzyme activities, such as superoxide dismutase (SOD), glutathione peroxidise (GPx), and catalase (CAT). Results showed that Nenas honey increased the level of DNA damage at the $1^{\text {st }}$ month but reduced it significantly at the $2^{\text {nd }}$ month as compared to control. GPx and CAT activities also decreased significantly with honey supplementation throughout the study, though no changes were observed in SOD activity. Fasting glucose levels remained within the normal range with honey supplementation. In conclusion, Nenas honey decreases oxidative stress which leads to a reduction of antioxidant enzyme activities in the body.
\end{abstract}

Keywords: honey, antioxidant, enzymes, DNA

Honey is a sticky, yellowish-brown, natural sweet substance produced by honey bees through a collection of nectar from many plants. From the chemical point of view, honey is a highly concentrated solution of a complex mixture of sugars (Pyrzynska \& Biesaga 2009). The specific composition of honey depends on the flower available to the bees producing the honey. The composition and the source of honey greatly dictates its biochemical properties (KISHORE et al., 2011). Honey is known to be rich in both enzymatic and non-enzymatic antioxidants, including glucose oxidase, catalase, ascorbic acid, flavonoids, phenolic acids, carotenoid derivatives, organic acids, Maillard reaction products, amino acids, and proteins (BALTRUŠAitytĖ et al., 2007).

Malaysia is well-known for its wide variety of honeys. Several types of Malaysian honey are Durian, Gelam, Nenas, and Coconut honey. Nenas honey is one of the most common monofloral Malaysian honeys and the floral source is from Ananas comosus spp. (common name Nenas) trees. The honeys were named according to their floral sources. Other than being a natural sweetener, honey also serves as a dietary antioxidant. The amount, composition, and type of the antioxidants in honey depend on the floral source used to collect nectar from, seasonal and environmental factors, as well as processing (GHELDOF et al., 2003).

There is a growing demand of natural products in human diet due to the possible negative effects of synthetic food additives on human health (BALTRUŠAITYTĖ et al., 2007). Honey

\footnotetext{
* To whom correspondence should be addressed.

Phone: +65 03 92897293; fax: +65 03 26938037; e-mail: joaan@medic.ukm.my
} 
is one of the natural food products that is well-known for its high nutritional and prophylactic medicinal value (Pyrzynska \& Biesaga, 2009). The antioxidative properties in honey have been proven effective in aiding the healing process of wounds and burns, diabetic ulcers, cancer, cardiovascular and neural diseases (TAN et al., 2009; EREJUwA et al., 2010; KHALIL et al., 2010). In addition, honey also helps to improve spatial memory and reduces the anxiety in aging mice, and has antimicrobial properties that act effectively against human pathogenic microorganisms (PAUL et al., 2007; CHEPULIS et al., 2009).

Reactive oxygen species (ROS), which include superoxide anion $\left(\mathrm{O}_{2}^{-}\right)$, hydrogen peroxide $\left(\mathrm{H}_{2} \mathrm{O}_{2}\right)$, and the hydroxyl radical $(\mathrm{OH} \cdot)$ generated as by-products of cellular metabolism primarily in the mitochondria, have been implicated as causes of aging and disease. With time, the accumulation of ROS overwhelms the body's antioxidant defence and results in oxidative stress. The term oxidative stress describes the lack of equilibrium between the free radicals generated and the antioxidant protective activity in a given organism (RATNAM et al., 2006). Among other factors that contribute to ROS formation are smoking, pollutants, stress, excessive physical exercise, and ultraviolet rays (BLock et al., 2002).

The human body uses a defence mechanism known as the antioxidant network to fight against these free radicals and ROS. In this network, there are antioxidant enzymes, such as SOD, GPx, and CAT, that help in scavenging the free radicals (NAITO et al., 2010). In addition, there are radical-scavenging substances, such as coenzyme Q10, vitamins A, C, and E, that act on the free radicals and eliminate them directly (KuTLu et al., 2005; KNOWLdEN, 2012). Beside this, the body also has repair and regenerative activities that act on lipids, proteins, and DNAs that have been damaged by free radicals. The primary enzymes that are involved in these activities are phospholipase, protease, transferase, and DNA repair enzymes (NAITO et al., 2010).

Despite the existence of a well-structured antioxidant network, oxidative stress does occur when there is an imbalance between free radical formation and the mentioned defence mechanism. Free radicals can travel through the cell disrupting the structure of other molecules and resulting in cellular damage, which contributes to aging and various health problems. Antioxidant that occur naturally in the body or are consumed through the diet may block damage to cells. However, over time, damage cells can accumulate and lead to age related diseases. As such, humans need to protect themselves from these damaging compounds by absorbing antioxidants from high antioxidant food (KHALIL et al., 2010).

Therefore, it is vital to cater the availability of antioxidants by manipulating diet and life style of individuals in aid of the existing network. In an effort to combat the free radical activities, various studies have been done to determine the effect of diet and dietary supplementation in increasing the individual's antioxidant level (GHELDOF \& ENGESETH, 2002; RATNAm et al., 2006; EREJuWA et al., 2010). Antioxidant properties of honey have often been highlighted because they act as protective elements against aging and other age related diseases by scavenging ROS (KNOWLDEN, 2012).

Malaysian honeys that have been studied are Tualang and Gelam honey. Studies have reported the benefits of both Tualang and Gelam honey but research on the Nenas honey is still scarce (DyrbyE et al., 2005; TAN et al., 2009). Recently, HusSEIN and co-workers (2011) reported that Gelam and Nenas honeys have comparatively higher antioxidant reducing power as compared to honey from Croatia, whereas Gelam honey has a higher radical scavenging activity as compared with commercial Indian honey.

Nenas honey has been implicated to contain various antioxidant components. However, it has yet to be tested as an antioxidant supplement. Therefore, the aim of this work was to evaluate the effect of Nenas honey in modulating the oxidative status of young adults as a 
preventive measure to limit oxidative damage with age. We hope that this preliminary report will promote the use of this honey as an antioxidant in the future.

\section{Materials and methods}

\subsection{Nenas honey}

The Malaysian Nenas honey used in this research was similar to that studied by HuSSEIN and co-workers (2011), where flavonoid and phenolic contents in Nenas honey were found to be the major components responsible for its antioxidant activity. The honey was purchased from the Department of Agriculture, Batu Pahat, Johor, Malaysia, the floral source was from the Ananas comosus spp. tree.

\subsection{Subjects}

The subjects recruited for this study were 21-23 years old medical students of the Universiti Kebangsaan Malaysia Medical Centre (UKMMC). They were physically healthy, not taking any form of antioxidant supplementations, nor practicing any form of regular exercise for the last three months. Students with medical illness, smoking, or taking alcohol were excluded from this study. Prior to the commencement of the study, informed consents were obtained from all participants and demographic data, which included age, weight, height, body mass index (BMI), gender, and ethnic group, were also recorded. The subjects were assigned into two groups: control group and supplemented group. The supplemented group was given 1 tablespoon of Nenas honey every day for 2 months. Fasting blood samples were taken at baseline ( 0 month $), 1^{\text {st }}$ and $2^{\text {nd }}$ month from both groups. Participants were instructed to fast for 10 hours before blood sample collection.

\subsection{Detection of DNA damage}

DNA damage was determined by using comet assay (SING et al., 1988). Briefly, $5 \mu 1$ of fresh whole blood was mixed with $70 \mu 10.6 \%$ low melting agarose in microcentrifuge tubes. The cell suspension was then embedded onto frosted microscope slides with $0.6 \%$ normal melting agarose and lysed with cold lysing solution. After the denaturation of DNA by the alkaline solution, neutralization buffer was used to neutralize the excess alkali, then electrophoresis was done and slides were viewed by an epifluorescent microscope.

\subsection{Glutathione peroxidase (GPx) assay}

The antioxidant enzymes activities, GPx, SOD, and CAT were measured using a spectrophotometer. The GPx activity was determined based on the method by PAGLIA and VALENTINE (1967). Hemolysates $(200 \mu \mathrm{l})$ were diluted with $0.8 \mathrm{ml}$ distilled water and mixed with $1 \mathrm{ml}$ of cyanmethaemoglobin reagent before adding to a substrate mixture. It consisted of $0.05 \mathrm{M}$ phosphate buffer ( $\mathrm{pH} 7.0$ ), $5 \mathrm{mM}$ ethylenediamine tetraacetate (EDTA), $1.125 \mathrm{M}$ sodium azide $\left(\mathrm{NaN}_{3}\right), 8.4 \mathrm{mM}$ reduced nicotine adenine dinucleotide phosphate (NADPH), $10 \mathrm{U} \mathrm{ml}^{-1}$ glutathione reductase, and $0.15 \mathrm{M}$ reduced glutathione $(\mathrm{GSH})$. A volume of $0.1 \mathrm{ml} \mathrm{H}_{2} \mathrm{O}_{2}(2.2$ $\mathrm{mM}$ ) was added to $2.9 \mathrm{ml}$ of the reaction mixture and the reaction was followed by a change in absorbance for $5 \mathrm{~min}$ at $340 \mathrm{~nm}$. A control was also run by replacing the haemolysate with distilled water. One unit of GPx was defined as the amount of enzyme that would oxidize $1 \mu \mathrm{M}$ NADPH to $\mathrm{NADP}^{+}$per min at $25^{\circ} \mathrm{C}$ and $\mathrm{pH}$ 8.0. 


\subsection{Superoxide dismutase (SOD) assay}

SOD activity was determined according to BEYER and FRIDOVICH (1987). Blood samples to be analysed were mixed with an equal volume of distilled water to prepare haemolysates. The substrate solution was made up of $50 \mathrm{mM}$ phosphate buffer ( $\mathrm{pH}$ 7.0), $0.2 \mathrm{M}$ L-methionine, $1.72 \mathrm{mM}$ nitro blue tetrazolium (NBT), and 1\% Triton X-100. The haemolysate $(20 \mu \mathrm{l})$ was added to $1 \mathrm{ml}$ substrate solution and the mixture was reacted with $10 \mu \mathrm{l}$ riboflavin $(0.117$ $\mathrm{mM}$ ) in a brightly illuminated aluminium foil-lined box containing two $20 \mathrm{~W}$ Sylvania GroLux fluorescent lamps for $7 \mathrm{~min}$. A control tube in which the sample was replaced by phosphate buffer was run in parallel and the absorbance was measured at $560 \mathrm{~nm}$. One unit of SOD was defined as the amount of enzyme that would inhibit the rate of reduction of NBT by $50 \%$ at $25^{\circ} \mathrm{C}$ at $\mathrm{pH} 7.8$.

\subsection{Catalase (CAT) assay}

CAT activity was determined according to AEBI (1984). The haemolysate was derived by mixing RBC pellet with cold distilled water. The haemolysate was mixed with phosphate buffer and then with $30 \mathrm{mM}$ hydrogen peroxide to initiate the reaction in which the decrease in absorbance was measured at $240 \mathrm{~nm}$ wavelength. One unit of CAT was defined as the amount of enzyme that would decompose $1 \mu \mathrm{M} \mathrm{H}_{2} \mathrm{O}_{2}$ per second at $25^{\circ} \mathrm{C}$ and $\mathrm{pH}$ 7.0.

\subsection{Haemoglobin content}

The haemoglobin content of all haemolysates was determined in duplicate with a haemoglobin assay kit (catalogue number 6210) by Eagle Diagnostic (USA). Briefly, a haemoglobin concentration standard curve was prepared with cyanmethaemoglobin standard and reagent according to the manufacturer's guide. The haemolysates used in SOD $(30 \mu 1)$, GPx $(100 \mu l)$, and CAT $(20 \mu \mathrm{l})$ analysis were mixed with cyanmethaemoglobin reagent of $4 \mathrm{ml}$ and the absorbances were read at $540 \mathrm{~nm}$.

\subsection{Statistical analysis}

Results obtained were expressed as mean \pm standard deviation (SD). Statistical significance was taken at $\mathrm{P}<0.05$. All data analysis was performed using SPSS version 13.0. Changes in the measured parameters at each follow-up were analysed using ANOVA.

\section{Results and discussion}

A total of 23 subjects completed the study where 11 of them were male and 10 females. The subjects were from three main ethnic groups; Malay (78.26\%), Chinese (13.04\%) and Indian $(8.7 \%)$. This data relatively mirrored the population of medical students in the Universiti Kebangsaan Malaysia Medical Centre. Several subjects from both groups dropped out from the study; however, the mean demographic characteristics remained unaltered. Of the 30 subjects enrolled at the beginning, 23 subjects (10 controls and 13 supplemented) completed the study.

Medical students were selected for this study as they have been identified as young adults with the highest risk of stress due to exposure to stressful environment, such as examinations, clinical works, and hectic schedules (Dyrbye et al., 2005). The build-up of these stress factors may result in oxidative stress. This corresponds to our result, which 
showed considerable high level of DNA damage in both control and supplemented group at the beginning of the study. Though the number of subjects studied was small, our results revealed interesting roles of Nenas honey, which prelude future research.

\subsection{Blood glucose}

Both groups of subjects showed no significant changes in the glucose level throughout the study (Table 1). Despite the high glucose content of honey, this result indicated that daily consumption of 1 tablespoon of Nenas honey had no effect on the blood glucose level.

Table 1. Fasting glucose levels in control and supplemented group at $0,1^{\text {st }}$, and $2^{\text {nd }}$ month

\begin{tabular}{lccc}
\hline & \multicolumn{3}{c}{ Mean $\pm \operatorname{SD}\left(\mathrm{mmol} \mathrm{1}^{-1}\right)$} \\
\cline { 2 - 4 } & 0 & $1^{\text {st }}$ & $2^{\text {nd }}$ \\
\hline Control & $5.65 \pm 1.04$ & $5.73 \pm 0.67$ & $5.38 \pm 0.22$ \\
Supplemented & $5.24 \pm 0.40$ & $5.37 \pm 0.39$ & $5.25 \pm 0.41$ \\
\hline
\end{tabular}

\subsection{DNA damage}

Interestingly, supplementation with Nenas honey demonstrated a non-expected hormesis effect, where the level of DNA damage was found to increase at the $1^{\text {st }}$ month of supplementation and decreased at the $2^{\text {nd }}$ month (Fig. 1). These results suggest a novel role of Nenas honey, whereby it could stimulate the antioxidant system or the DNA repair mechanism by initiating an increased level of oxidative stress at the early stage of supplementation. The decreased level of DNA damage thereafter is evidence of this hormesis effect.

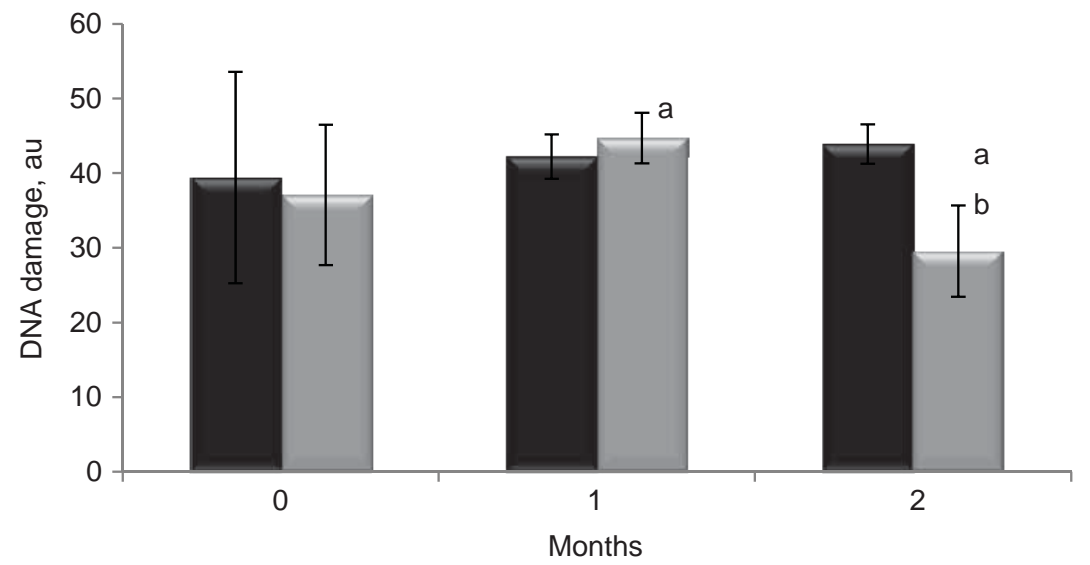

Fig. 1. DNA damage in supplemented and control groups at $0,1^{\text {st }}$, and $2^{\text {nd }}$ month.

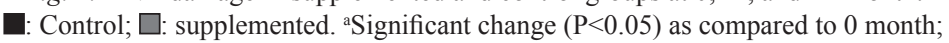
${ }^{\mathrm{b}}$ significant change $(\mathrm{P}<0.05)$ as compared to 1 month

Our findings are similar with the results obtained by YAO and co-workers (2011), where DNA damage was found to decrease significantly with Gelam honey supplementation. Our results also support previous studies, which claimed that Nenas honey has the ability to scavenge free radicals (HuSSEIN et al., 2011; KISHORE et al., 2011). Quercetin, which is the 
second most abundant flavonoid in Nenas honey, prevents DNA damage by incorporating into the red blood cells structure to provide defence and promote cell function (AlvarezSUAREZ et al., 2012). Elsewhere, flavonoids in the honey decrease oxidative stress by trapping reactive oxygen species, inhibiting enzymes responsible for producing superoxide anions, chelating transition metals involved in processes forming radicals, and preventing the peroxidation process by reducing alkoxyl and peroxyl radicals (PYrZYNSKA \& BIESAGA, 2009).

\subsection{Antioxidant enzyme}

The supplemented group had decreased GPx activity at $1^{\text {st }}$ and $2^{\text {nd }}$ month as compared to the baseline (Fig. 2). Conversely, there were no significant changes observed in the GPx activity for control group throughout the study. As for CAT enzyme, its activity decreased significantly in the supplemented group at the $2^{\text {nd }}$ month but showed no significant changes in the control group (Fig. 3). Unlike the mentioned enzymes, SOD activity did not change significantly in either group of subjects.

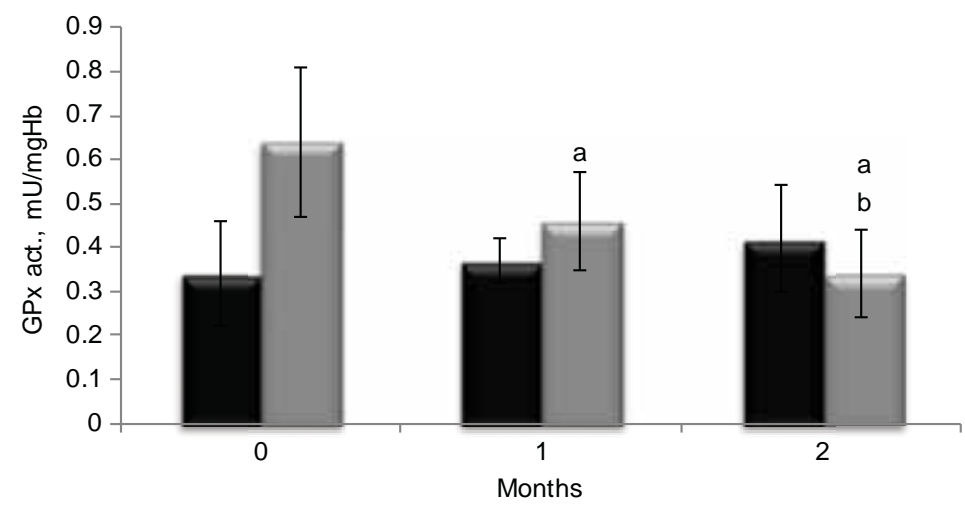

Fig. 2. GPx activities in supplemented and control groups at $0,1^{\text {st }}$, and $2^{\text {nd }}$ month.

a: Control; $\square$ : supplemented. ${ }^{\text {a }}$ Significant change $(\mathrm{P}<0.05)$ as compared to 0 month.

b Significant change $(\mathrm{P}<0.05)$ as compared to 1 month

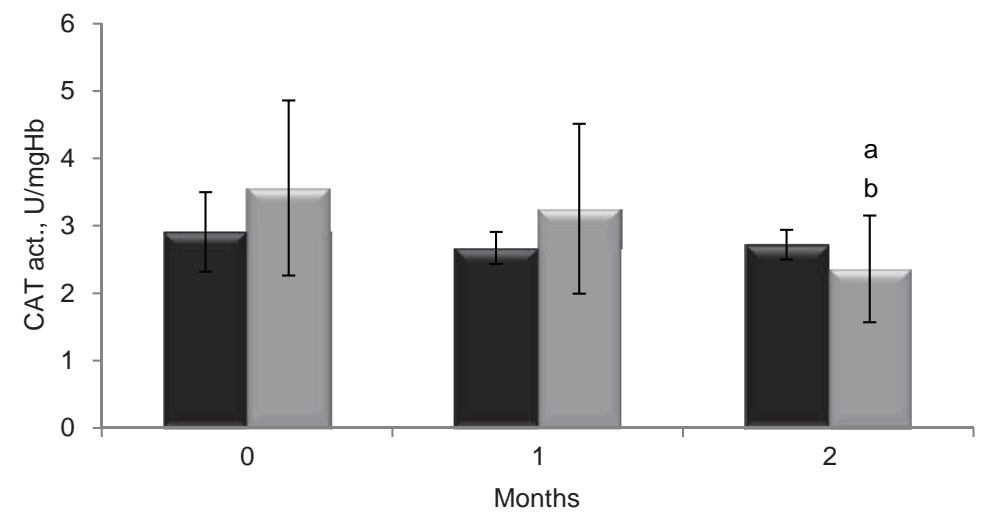

Fig. 3. CAT activities in supplemented and control groups at $0,1^{\text {st }}$, and $2^{\text {nd }}$ month.

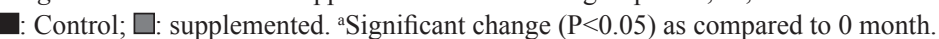

${ }^{\mathrm{b}}$ Significant change $(\mathrm{P}<0.05)$ as compared to 1 month 


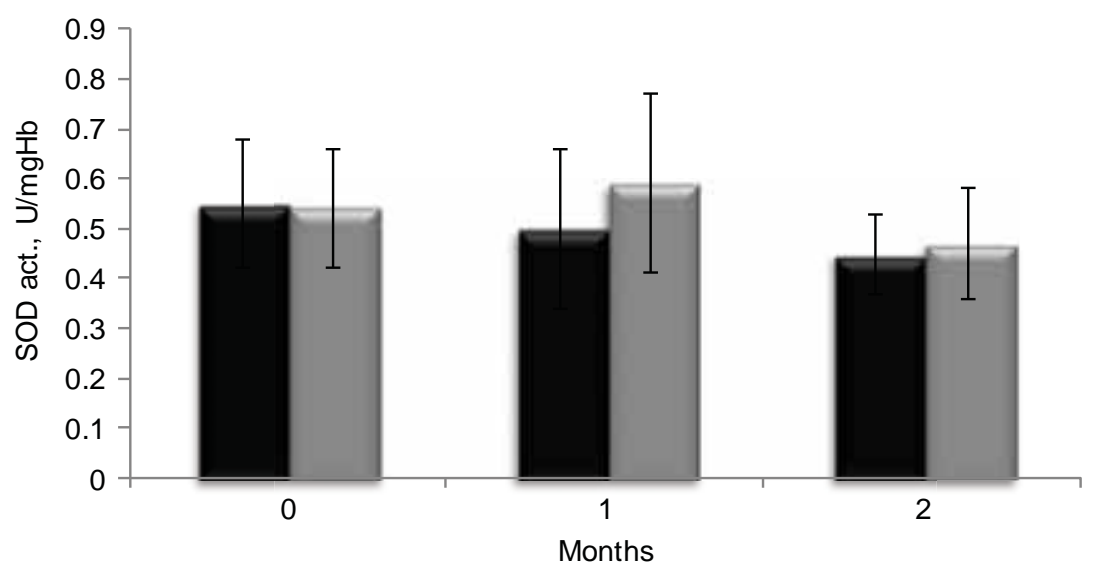

Fig. 4. SOD activities in supplemented and control groups at $0,1^{\text {st }}$, and $2^{\text {nd }}$ month.

口: Control; $\square$ : supplemented

As GPx, CAT, and SOD function to scavenge free radicals, their activities depend largely on the amount of free radicals and ROS present in the human body (NAITO et al., 2010). Our findings correspond to the study by EREJUWA and co-workers (2009), which also presents reduction in antioxidant enzyme activities with honey supplementation. This might be the result of lower amount of free radicals available to activate the antioxidant enzymes as shown by reduction in oxidative DNA damage among the supplemented subjects. This also indicates that honey attenuates the changes in antioxidant enzymes in response to oxidant generation (EREJUWA et al., 2010).

\section{Conclusions}

The substitution of honey in some foods for traditional sweeteners has been suggested to result in an enhanced antioxidant defence system in healthy adults (SCHRAMm et al., 2003). In line with that, our data suggest that Nenas honey in particular can act as an antioxidant agent, either through the direct antioxidant effect of flavonoids and phenolics or stimulation of DNA repair in the human body by its residues, which finally produce beneficial effects to health.

In conclusion, supplementation of Nenas honey improved the oxidative status of medical students. This study highlights the relevance of honey supplementation at an early stage of life, such as young adults, to prevent further oxidative damage with age. Therefore, more investigations are highly recommended to elucidate the potential use of Nenas honey as a natural antioxidant supplement in advanced age and also in oxidative stress associated diseases.

We wish to thank the Faculty of Medicine, Universiti Kebangsaan Malaysia (UKM) for the UKM short-term grant FF-069-2011. 


\section{References}

AeBi, H. (1984): Catalase in vitro. Meth. Enzymology, 105, 121-126.

Alvarez-Suarez, J.M., Giampieri, F., González-Paramás, A.M., Damiani, E., Santos-Buelga, C.\& Battino, M. (2012): Phenolics from monofloral honeys protect human erythrocyte membranes against oxidative damage. Fd Chem. Toxicol., 50, 1508-1516.

BaltruŠaityté, V., Venskutonis, P.R. \& ČEKSTERYté, V. (2007): Radical scavenging activity of different floral origin honey and beebread phenolic extracts. Fd Chem., 101, 502-514.

Beyer, W.F.\& Fridovich, I. (1987): Assaying for the superoxide dismutase activity: some large consequences of minor changes condition. Anal. Biochem., 161, 559-566.

Block, G., Dietrich, M., Norkus, E.P., Morrow, J.D., Hudes, M., CaAn, B. \& Packer, L. (2002): Factors associated with oxidative stress in human population. Am. J. Epidemiology, 156, 276-285.

Chepulis, L.M., Starkey, N.J., Waas, J.R. \& Molan, P.C. (2009): The effects of long-term honey, sucrose or sugarfree diets on memory and anxiety in rats. Physiol. Behaviour, 97, 359-368.

Dyrbye, L.N., Thomas, M.R.\& Shanafelt, T.D. (2005): Medical student distress; causes, consequences, and proposed solutions. Mayo Clin. Proc., 80, 1613-1622.

Erejuwa, O.O., Sulaiman, S.A., Ab Wahab, M.S., Sirajudeen, K.N.S.\& Salzihan, M.S. (2009): Effects of Malaysian Tualang honey supplementation on glycemia free radical scavenging enzymes and markers of oxidative stress in kidneys of normal and streptozotocin-induced diabetic rats. Int. J. Cardiology, 137, S45.

Erejuwa, O.O., Sulaiman, S.A., Wahab, M.S.A., Sirajudeen, K.N.S., Salleh, M.S.M.\& Gurtu, S. (2010): Antioxidant protective effect of glibenclamide and metformin in combination with honey in pancreas of streptozotocin-induced diabetic rats. Int. J. Molecular Sci., 11, 2056-2066.

Gheldof, N.\&Engeseth N.J. (2002): Antioxidant capacity of honeys from various floral sources based on the determination of oxygen radical absorbance capacity and inhibition of in vitro lipoprotein oxidation in human serum samples. J. Agric. Fd Chem., 50, 3050-3055.

Gheldof, N., WANG, X.H.\&Engeseth, N.J. (2003): Buckwheat honey increases serum antioxidant capacity in humans. J. Agric. Fd Chem., 51, 1500-1505.

Hussein, S.Z., Yusoff, K.M., MakPol, S. \& Yusof, Y.A.M. (2011): Antioxidant capacities and total phenolic contents increase with gamma irradiation in two types of Malaysian honey. Molecules, 16, 6378-6395.

Khalil, M.I., Sulaiman, S.A.\&BoukraA, L. (2010): Antioxidant properties of honey and its role in preventing health disorder. Open Nutraceuticals J., 3, 6-16.

Kishore, R.K., Halim, A.S., Syazana, M.S. \& Sirajudeen, K.N.S. (2011): Tualang honey has higher phenolic content and greater radical scavenging activity compared with other honey sources. Nutr. Res., 31, 322-325.

KNOwLDEN, A. (2012): Role of antioxidant supplementation in response to exercise induced oxidative stress. www. abcbodybuilding.com, accessed 19 April 2012

Kutlu, M., Naziroglu, M., Simsek, H., Yilmaz, T.\& Sahap Kükner, A. (2005): Moderate exercise combined with vitamin $\mathrm{C}$ and $\mathrm{E}$ counteracts oxidative stress in the kidney and lens of streptozotocin-induced diabetic rats. Int. J. Vitamin Nutr. Res., 75, 71-80.

Naito, Y., Lee, M.C.I., Kato, Y., Nagai, R.\& Yonei, Y. (2010): Oxidative stress markers. Japanese Soc. Anti-Aging Med., 7, 36-44.

Paglia, D.E. \& Valentine, W.N. (1967): Studies on the quantitative and qualitative characterization of erythrocyte glutathione peroxidase. J. Lab. Clin.Med., 70, 158-169.

Paul, I.M., Beiler, J., McMonagle, A., Shaffer, M.L., Duda, L.\& Berlin JR, C.M. (2007): Effect of honey, dextromethorphan, and no treatment on nocturnal cough and sleep quality for coughing children and their parents. Arch. Pediatrics \& Adolescent Med., 161, 1140-1146.

Pyrzynska, K. \& Biesaga, M. (2009): Analysis of phenolic acids and flavonoids in honey. Trends Anal. Chem., 28, 893-902.

Ratnam, D.V., Ankola, D.D., Bhardwaj, V., Sahana, D.K.\& Kumar, M.N.V. (2006): Role of antioxidants in prophylaxis and therapy: a pharmaceutical perspective. J. Controlled Release, 113, 189-207.

Schramm, D., Karim, M., Schrader, H.R., Hotl, R.R., Cardetti, M. \& Keen, C.L. (2003): Honey with high levels of antioxidants can provide protection to healthy human subjects. J. Agric. Fd Chem., 51, 1732-1735.

Sing, N.P., Stephen, R.E.\& Schneider, E.L. (1988): A simple technique for quantitation of low levels of DNA damage in individual cells. Expl Cell Res., 175, 184-191. 
Tan, H.T., Rahman, R.A., Gan, S.H., Halim, A.S., Hasan, A.S., Sulaiman, S.A.\& Kirnpal-Kaur, B. (2009): The antibacterial properties of Tualang honey against wound and enteric microorganisms in comparison to Manuka honey. BioMed Central Complementary Alternative Med., 15, 34.

Yao, L.K., RaZAK, S.L.A., Ismail, N., Fai, N.C., Asgar, M.H.A.M., Sharif, N.M., Goon, J.A. \& Jubri, Z. (2011): Malaysian gelam honey reduces oxidative damage and modulates antioxidant enzyme activities in young and middle aged rats. J. Medl Pl. Res., 5, 5618-5625. 